\title{
A posição do Brasil na governança financeira global: um estudo da conformidade entre o posicionamento do governo brasileiro e o consenso expresso nos comunicados oficiais do G20 e do FMI (2006-2012)
}

Brazil's position in global financial governance: studying the similarity between the Brazilian government's position and the consensus expressed by the G20 and IMF's official statements (2006-2011)

Marcelo Waldvogel* Maria Antonieta Del Tedesco Lins**

\section{Resumo}

As economias emergentes têm gradualmente alcançado maior espaço nas deliberações multilaterais a respeito da governança econômica global em um quadro de reorganização da ordem mundial. Esta ascensão ocorre em níveis e ritmos distintos em diferentes instâncias da governança econômica global, como, por exemplo, no âmbito de instituições financeiras e fóruns de discussão multilaterais. 0 artigo investiga, por meio de análise quantitativa textual, o nível de conformidade entre as posições oficiais de uma economia emergente, o Brasil, e o posicionamento manifesto nos comunicados oficiais destas duas instituições internacionais, o FMI e o G20. Ao mostrar que, entre 2006 e 2012, os comunicados do G20 se aproximaram mais das posições brasileiras do que os consensos expressos pelo FMI, os resultados do estudo dão sustentação ao fenômeno extensamente discutido na literatura sobre a necessidade de reformulação da estrutura de governança do FMI com o intuito de ampliar voz e voto dos países emergentes. O G20, como uma organização não formalizada, oferece o espaço e a flexibilidade para os países emergentes se posicionarem.

Palavras-chave: Governança financeira global; FMI; G20; economias emergentes; ordem global.

\section{Abstract}

Emerging economies have gradually attained more influence in multilateral discussions global economic governance in the context of reorganization of the global order. This rising has been taking place at different levels and paces in different arenas of global economic governance, such as multilateral financial institutions and discussion forums. The present study intends to investigate the level of

\footnotetext{
* Mestre em Relações Internacionais pela Universidade de São Paulo.

** Doutora em Economia pela FGV-SP e professora do Instituto de Relações Internacionais da Universidade de São Paulo.
} 
conformity between the official positions of the government of an emerging economy, Brazil, and the collective positions expressed in the official communiqués of two international institutions, the IMF and the G20. By demonstrating that, between 2006 and 2012, the G20 communiqués had more proximity to the Brazilian positions than the consensus expressed by the IMF, the results of this study provide support to the extensively discussed phenomenon of the need for reform of the IMF governance structure in order to amplify both voice and vote of the emerging economies. The G20, as an informal organization, provides the room and the flexibility the emerging economies need to make their stand.

Keywords: Global financial governance; IMF; G20; emerging economies; global order. 


\section{Introdução}

As inquietações em torno de uma eventual reforma da governança financeira internacional se intensificaram no final da década de 1990 como um desdobramento natural das crises financeiras que devastaram algumas economias emergentes naquele momento. Seja por novas combinações de fatores como determinantes das crises, seja pelos programas de ajustamento negociados com organismos multilaterais e seus efeitos, ou ainda pelos custos econômicos e sociais das turbulências, a partir da crise asiática de 1997, foi crescente o mal-estar dos países emergentes com a ordem financeira vigente. Neste cenário e diante da constatação de que o G7 deveria incluir países emergentes na discussão dos desdobramentos da crise na Ásia, foi criado o Grupo dos Vinte (G20), uma rede intergovernamental informal que reúne as vinte maiores economias do mundo, incluindo a União Europeia como bloco. Inicialmente um fórum de ministros de finanças e presidentes de bancos centrais, o G20 procurava construir consensos em torno de estratégias para administração de crises (WOODS, 2010b).

O Fundo Monetário Internacional (FMI ou Fundo), uma das instituições financeiras internacionais concebidas na conferência de Bretton Woods em 1944, tem como função principal assegurar a estabilidade do sistema monetário internacional - o que significa garantir o funcionamento dos sistemas de taxas de câmbio e sistemas de pagamento internacionais - e, desde 2012, incluiu em seu mandato cláusulas relacionadas com a estabilidade global.1 Diferentemente do G20, o FMI é uma instituição multilateral formal, comandada e controlada pelos países que a compõem. Desde sua criação, o FMI é o principal interlocutor de todo e qualquer país com problemas no balanço de pagamentos. Com a elevada intensificação dos fluxos internacionais de capitais a partir da década de 1990, os desequilíbrios nas contas externas de um país passaram a ter potenciais impactos para além das fronteiras nacionais.

A recorrência das crises financeiras e a eclosão da crise iniciada nos Estados Unidos em 2008, tornada global em pouco tempo, fizeram com que as agendas do FMI e do G20 tivessem vários pontos comuns. Mais do que isto, dada a estrutura de governança do Fundo, suas funções como emprestador e os interesses particulares de seus membros, as duas instituições passaram a oferecer espaços complementares onde os países poderiam se posicionar frente às grandes questões da governança financeira internacional.

São, portanto, organismos com natureza, composição, estrutura e governança institucionais muito diferentes, mas cuja atuação tem pontos de contato críticos no que concerne à dinâmica do sistema monetário e financeiro internacional. Isto significa que, apesar de diferenças essenciais, estas instituiç̧ões possuem aspectos de sua missão que se sobrepõem. As políticas

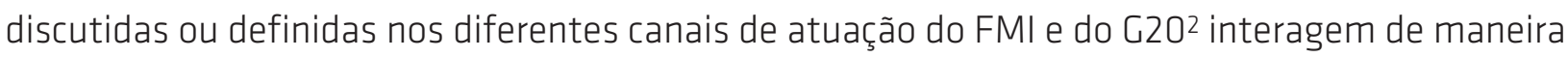
complexa para afetar a governança financeira global. Os países membros podem escolher alternadamente um dos dois espaços institucionais para apresentar diferentes posições. O fato de o G20 não ter poder deliberativo também é um fator determinante da dinâmica e do posicionamento dos países nas reuniões.

\footnotetext{
1 Informações disponiveis no portal do FMl, em: <http://www.imf.org/external/np/exr/facts/glance.htm>.

2 Em que pese ser o G20 um organismo sem poder deliberativo, como será discutido adiante.
} 
Em meio a estas instituições, as economias emergentes foram mudando suas posições e posturas no sistema internacional. Em primeiro lugar, muitos países passaram por importantes reformas financeiras e macroeconômicas após suas crises nacionais e regionais. Adicionalmente, o período de elevada liquidez e prosperidade nas economias industrializadas até 2007, conhecido como a "Grande Moderação", assim como o intenso crescimento de países emergentes como a China, permitiu a muitas economias uma expressiva acumulação de reservas internacionais, como autoproteção contra crises, dentre outras motivações (CHIN, 2011).

O Brasil desempenhou um papel importante no debate sobre a arquitetura internacional no período em torno da crise de 2008. Com a economia estabilizada, crescendo e em franco processo de acumulação de reservas em 2006, a crise pegou a economia brasileira em um momento de bonança. A reputação do país como um poder emergente se consolidou no período. Nos anos seguintes, em condições menos favoráveis, a atuação do Brasil seguiu no foco das atenções. O recorte temporal do estudo leva em conta a fase de auge do fortalecimento da imagem internacional do Brasil nos fóruns de governança econômica global.

0 artigo investiga o nível de conformidade entre as posições oficiais de uma economia emergente, o Brasil, e o posicionamento manifesto nos comunicados oficiais destas duas instituições internacionais, o FMI e o G20. Para documentar o posicionamento oficial do país, a análise considerou os communiqués do International Monetary and Financial Committee (IMFC) do FMI e do G20 ministerial, ambos órgãos de nível ministerial das referidas instituições.

O trabalho parte da premissa de que as economias emergentes utilizam sua atuação nas instituições multilaterais como parte de uma estratégia de consolidação de sua posição relativa no sistema internacional. Assim, com base nos posicionamentos de governo - por parte do ministro da Fazenda brasileiro - foram aplicadas técnicas de análise qualitativa e quantitativa de dados textuais. Como hipótese para a análise empírica, consideramos a seguinte formulação: "o consenso expresso no âmbito do G20 apresenta maior conformidade em relação ao posicionamento oficial do governo do Brasil do que o consenso expresso no âmbito do FMl".

Após esta introdução, o item 1 descreve o objeto de estudo e a metodologia de análise de dados textuais. A posição do governo brasileiro e, portanto, os temas considerados mais prementes para o país na discussão sobre a governança financeira internacional, é sumarizada no item 2. Estabelecidas as categorias temáticas relevantes, o item 3 traz estudo comparativo dos communiqués das duas instituições frente às posições defendidas pelo governo brasileiro e analisa os resultados obtidos. Por último, se conclui.

\section{Descrição do objeto de estudo e da análise de dados textuais}

Para investigar o nivel de conformidade entre as posições oficiais de uma potência emergente em particular, o Brasil, e o posicionamento manifesto nos comunicados oficiais de duas instituições internacionais - o FMI e o G20 - foram aplicadas três técnicas distintas da metodologia de análise de conteúdo: análise qualitativa de dados textuais, análise quantitativa de dados textuais clássica e análise quantitativa de dados textuais informatizada. 
A definição pela análise quantitativa de dados textuais presentes nos communiqués dos encontros de alto nível de ambas as instituições, tanto do G20 ministerial quanto do IMFC, se dá em função dos seguintes aspectos metodológicos:

- composição: o IMFC é composto de autoridades econômicas de governos de 24 países, e o G20 ministerial de 19 países e da União Europeia. Conforme ilustrado na figura abaixo, não somente os membros apresentam um perfil similar como, são, em grande medida, os mesmos países. ${ }^{3}$

\begin{tabular}{|c|c|c|}
\hline $\begin{array}{l}\quad \text { G20 } \\
\\
\text { Coreia do Sul } \\
\text { México } \\
\text { Turquia } \\
\text { União Europeia }\end{array}$ & $\begin{array}{l}\text { África do Sul } \\
\text { Alemanha } \\
\text { Arábia Saudita } \\
\text { Argentina } \\
\text { Austrália } \\
\text { Brasil } \\
\text { Canadá } \\
\text { China } \\
\text { Estados Unidos } \\
\text { França } \\
\text { Índia } \\
\text { Indonésia } \\
\text { Itália } \\
\text { Japão } \\
\text { Reino Unido } \\
\text { Rússia }\end{array}$ & $\begin{array}{l}\quad \text { IMFC } \\
\text { Argélia } \\
\text { Bélgica } \\
\text { Emirados Árabes } \\
\text { Espanha } \\
\text { Gabão } \\
\text { Holanda } \\
\text { Suécia } \\
\text { Suíça }\end{array}$ \\
\hline
\end{tabular}

Figura 1 - Nacionalidades dos membros do G20 e do IMFC na Reunião Anual do Fundo em $2012^{4}$

- temática: ambos os órgãos - IMFC e G20 ministerial - concentram suas declarações oficiais em aspectos relevantes da governança econômica global, o que equaliza o espectro temático do material formalizado nos communiqués.

- nivel de representação: os referidos communiqués sumarizam as discussões, as diretrizes e as decisões estabelecidas no âmbito dos encontros de representantes econômicos de alto nível nomeados pelo governo de cada país membro, via de regra, ministros da Fazenda e presidentes de banco central, o que garante o mesmo nivel de representação no debate para a elaboração dos communiqués de cada instituição;

- legitimidade: é possível entender a mensagem encontrada nos communiqués como o vetor resultante do consenso estabelecido a partir do debate entre as diferentes posições dos países membros ao longo de cada encontro, o que confere legitimidade ao documento;

3 Cabe mencionar que alguns países têm acordos de representação rotativa no IMFC, como Austrália e Coreia do Sul, os países nórdicos e alguns países do sudeste asiático.

4 Cabe lembrar o status particular da Espanha como "convidado permanente" do G20 desde 2009 (disponível em: <http://www.g20. org/docs/about/international_guests.html>. Acesso em: 05 mar. 2013), bem como o fato de que Bélgica, Holanda e Suécia têm sido indiretamente representados no G20, desde o início, por meio da União Europeia. 0 presidente do IMFC é, desde 2015, o presidente do Banco Central do México, Agustín Carstens. 
- regularidade: como os encontros do IMFC e do G20 ministerial são regulares, ambos ocorrendo duas vezes ao ano, torna-se possível uma análise comparativa da evolução do tratamento dos temas nas mensagens divulgadas nos respectivos communiqués ao longo do período analisado;

- Iongevidade: no caso do G20, foram estudados os communiqués dos encontros ministeriais do grupo não somente pela questão do nível de representação, mas também em função da maior longevidade dos encontros ministeriais, o que favorece uma comparação com os communiqués divulgados nos encontros do IMFC ao longo do período analisado.

Cabe notar que estes comunicados oficiais são o único canal institucional formal de que estas instituições dispõem para divulgar aos mercados e ao público em geral o conteúdo de suas deliberações e os resultados de seus encontros. Logo, eventuais variações na extensão dos textos dedicada a cada tema refletem, no mínimo, variações na atenção declarada a determinado tema naquele encontro. Sendo assim, a atenção declarada nestes comunicados oficiais públicos é efetivamente quantificável.

Em uma primeira etapa da pesquisa, foram identificadas categorias de análise capazes de dar conta dos temas da governança econômica global tratados nos textos dos communiqués divulgados pelo IMFC e pelo G20 financeiro ministerial, a partir da metodologia de definição de conjuntos de palavras-chave empregada pelo G20 Research Group (coordenado por John J. Kirton, da Universidade de Toronto). Dentre as onze categorias de análise utilizadas pelo G20 Research Group 5 para analisar o material produzido pelas autoridades governamentais nas reuniões formais do G20, foram aplicadas neste trabalho, em função de seu valor como núcleos do debate atual da governança econômica global, as seis categorias elencadas a seguir. ${ }^{6}$

- Arquitetura financeira internacional

- Crise financeira internacional

- Desequilíbrios globais

- Padrões e códigos financeiros internacionais

- Reforma de quotas e governança do Fundo Monetário Internacional

- Regulação financeira internacional

Em seguida, foi realizada uma análise qualitativa de dados textuais para a identificação dos principais temas relativos à governança econômica global que demandam a atenção destas instituições internacionais segundo a visão do Brasil - foram considerados para este levantamento somente discursos oficiais do ministro da Fazenda nas reuniões bianuais do IMFC, no período de 2006 a 2012.

5 G20 FINANCE MINISTERIALS, 1999 - Finance Ministerial Conclusions. Disponivel em: <http://www.g20.utoronto.ca/analysis/index.html>. Acesso em: 05 mar. 2013

6 As demais categorias empregadas pelo grupo - a saber, "Liberalização da conta corrente", "Mudança climática", "Paraísos fiscais e lavagem de dinheiro" e "Financiamento ao terrorismo" - não foram aplicadas aqui uma vez que se referem a temas menos centrais no debate atual a respeito da governança financeira global, não fazendo parte do foco do presente estudo. 
Na etapa seguinte, foi aplicada a metodologia de análise quantitativa de dados textuais clássica para a identificação de cada menção às mesmas categorias de análise nos communiqués selecionados. O critério de seleção dos comunicados oficiais utilizados nesta pesquisa foi a data de divulgação do comunicado, abrangendo um período de sete anos desde o primeiro semestre de 2006 até o segundo semestre de 2012. Deste modo, foram identificados 14 communiqués do IMFC e 14 communiqués do G20 ministerial ao longo do mesmo período.? Eventuais anexos aos comunicados que tratassem de temas específicos da governança econômica global, como, no auge da crise econômica e financeira internacional de 2008, anexos tratando da reforma e supervisão do sistema financeiro, foram considerados como segmentos especiais dos respectivos communiqués aos quais se encontravam vinculados e, portanto, foram igualmente computados na análise quantitativa. É importante ressaltar que a frequência semestral destes comunicados foi constante no caso do IMFC - um communiqué por semestre - e irregular no caso do G20 - apenas um communiqué anual nos três primeiros anos e dois communiqués em um mesmo semestre no processo de resolução da crise financeira internacional. ${ }^{8}$ Este fato em si mesmo não deixa de apontar para uma das diferenças entre as duas instituições, ao contrastar uma certa rigidez burocrática do IMFC - mantendo tradicionalmente uma reunião semestral - à maior adaptabilidade do G20 a responder aos eventos que marcam a conjuntura econômica mundial. ${ }^{9}$

$\mathrm{Na}$ etapa seguinte da pesquisa, foram identificadas graficamente, a partir da metodologia de análise quantitativa de dados textuais clássica, conforme empregada por Kirton (2010, Assessing 68 and G20 Performance 1975-2009; Apêndices E \& G, p. 18, 20), variações no espaço dedicado a cada tema analisado nos comunicados oficiais de ambas as instituições internacionais, a partir do número de palavras utilizadas sobre o total de palavras do documento (em percentual) e do número de parágrafos dedicados às demandas sobre o total de parágrafos do documento (em percentual), ${ }^{10}$ possibilitando a identificação da atenção dispensada por parte do IMFC e do G20 ministerial a cada uma das categorias que demandam maior atenção destas instituições segundo o governo brasileiro.

A aplicação da metodologia de análise quantitativa de dados textuais clássica, com extensivo envolvimento humano, conforme descrito acima, implica uma ênfase por parte do pesquisador no aspecto da validade da análise empírica. Por outro lado, há a questão

7 A exceção ficou por conta do breve communiqué da reunião do G20 ministerial do dia 23 de setembro de 2011, realizada em Washington DC, comunicado este que se restringiu a antecipar o debate a ser realizado na reunião subsequente do grupo, a qual teve lugar em Paris apenas três semanas depois, em 15 de outubro de 2011, esta, sim, com um communiqué padrão devidamente incluído nesta análise.

8 Communiqués do segundo semestre de 2009: G20 em 05 de setembro; IMFC em 04 de outubro; G20 em 07 de novembro. Communiqués do primeiro semestre de 2011: G20 em 19 de fevereiro; G20 em 15 de abril; IMFC em 16 de abril. Communiqués do primeiro semestre de 2012: G20 em 26 de fevereiro; C20 em 20 de abril; IMFC em 21 de abril.

9 Ainda que se considere o fato de que o G20 ministerial se reuniu com uma frequência maior que o IMFC na fase de coordenação internacional da resolução dos efeitos da crise econômica e financeira internacional por demanda direta da cúpula de líderes do G20, permanece o fato de que foi este colegiado, o G20 ministerial, e não o IMFC, que inclui praticamente todos os membros do G20 e ainda outros países, ou mesmo o Conselho de Governadores do FMI - réplica do Conselho Executivo do Fundo, mas em nível ministerial - aquele demandado para a tarefa entre os que gerem a governança econômica mundial justamente, segundo Woods (2010b, p. 5), em função de sua natureza mais ágil e pouco rígida.

10 Cabem aqui algumas observações específicas sobre a disposição do material analisado neste levantamento: os subtítulos e títulos em linhas exclusivas não são computados na contagem; cada número em datas é contado como uma palavra; as barras entre siglas e/ou palavras fazem com que ambas as partes sejam contadas como uma única palavra; e em parágrafos com itens separados por uma linha em branco cada item é contado como um parágrafo, conforme formato do comunicado original. 
da confiabilidade da análise empírica. A diferença entre os dois conceitos seria a de que, "[w] hereas reliability provides assurances that particular research results can be duplicated, (...) validity provides assurances that the claims emerging from the research are borne out in fact." (KRIPPENDORF, p. 213) Ocorre que se observa uma relação complexa entre estas duas propriedades da pesquisa empírica, conforme explicam Mikhaylov, Laver e Benoit:

Reliability is no guarantee of validity, however, and in practice validity tends to suffer in the pursuit of maximizing reliability. Indeed, the debate over computerized versus hand-coded content analysis largely revolves around the tradeoff between reliability and validity. (MIKHAYLOV; LAVER; BENOIT, 2008, p. 2-3)

Em função deste desafio metodológico, foi realizada uma etapa adicional para que a presente análise empírica passasse por uma verificação da confiabilidade dos resultados obtidos por meio da metodologia de análise quantitativa de dados textuais clássica. Para este fim, foram empregadas ferramentas informatizadas de quantitative textual analysis, capazes de extrair dados quantitativos de uma sequência de textos como a utilizada neste estudo. Este processo adicional garantiu que a análise empírica aqui descrita apresentasse tanto um esforço no sentido do aprimoramento de sua validade, com o extensivo envolvimento humano correspondente à análise quantitativa de dados textuais clássica, quanto do aprimoramento de sua confiabilidade, a partir da aplicação dos recursos das referidas ferramentas informatizadas no material analisado.

O valor do presente estudo - que analisa a conformidade sem identificar vetores de causalidade entre os referidos posicionamentos - está em trazer uma contribuição para a compreensão do complexo ambiente institucional internacional: a confirmação empírica do fato de que diferentes instituições internacionais assimilam e refletem as mudanças na ordem geopolítica global em níveis distintos de velocidade e profundidade - o que traz implicações de ordem prática para a definição da política externa de cada estado, em função do respectivo interesse nacional.

\section{Posicionamento oficial do governo brasileiro quanto aos temas da governança financeira global}

O posicionamento oficial do governo brasileiro ${ }^{11}$ no que diz respeito às seis categorias de temas da governança financeira global apresentadas acima foi extraído dos discursos oficiais da autoridade econômica deste governo nomeada formalmente governador do Brasil no âmbito do Fundo Monetário Internacional, o então ministro da Fazenda Guido Mantega, ${ }^{12}$ proferidos nos encontros da Assembleia Geral do International Monetary and Financial Committee (IMFC)

\footnotetext{
11 Apesar da possibilidade real de mudança de rumo nas políticas macroeconômicas e nas posições oficiais do Brasil quando da composição de um novo governo, a continuidade na equipe econômica nas duas administrações mais recentes ilustra a ausência de deslocamentos marcantes na visão brasileira dos temas da governança econômica global nos últimos anos.

12 O ministro da Fazenda representa o governo brasileiro tanto no G20 ministerial - ao lado do presidente do Banco Central do Brasil quanto no Conselho de Governadores do FMI - órgão no qual o presidente do Banco Central atua como governador alterno do Brasil.
} 
do FMI $^{13}$ no período analisado neste estudo, de 2006 a 2012. É importante notar que o estudo não incluiu os discursos do ministro da Fazenda na análise quantitativa pelo fato de que estes discursos não representam uma posição consensual, mas um comentário destinado a influenciar o consenso. Este fato altera o significado das frequências de palavras e expressões encontradas - pontos de divergência ocupam maior espaço nos discursos, enquanto que pontos importantes para o Brasil que encontrem eco no grupo são menos enfatizados. Assim, os discursos do ministro foram utilizados aqui em uma análise qualitativa, somente como parâmetro fixo para identificar os temas de interesse do Brasil. O quadro abaixo sumariza a posição oficial do governo brasileiro a respeito de cada uma das categorias estudadas:

Quadro 1 - Extratos de discursos do ministro da Fazenda do Brasil proferidos em reuniões do IMFC no período de 2006 a 2012

\begin{tabular}{|c|c|}
\hline CATEGORIA & EXTRATOS DOS DISCURSOS DO MINISTRO DA FAZENDA NO IMFC \\
\hline $\begin{array}{l}\text { Arquitetura } \\
\text { Financeira } \\
\text { Internacional }\end{array}$ & $\begin{array}{l}\text { - I/2012 "The IMF has given strong endorsement to the monetary policies in advanced } \\
\text { countries, including the recent measures taken by the European Central Bank. It has been } \\
\text { more reluctant, however, to support the defensive measures that some emerging economies } \\
\text { are being forced to deploy in response to spill-over effects of these policies. Capital account } \\
\text { management policies have yet to be fully accepted by the Fund as a normal part of economic } \\
\text { policy toolkit." } \\
\text { - II/2009 "We are in effect creating a new international economic order. (...) This new } \\
\text { international economic architecture has the G20 at the top of the pyramid, providing guidance } \\
\text { and support to international financial institutions. (...) A renewed and more legitimate Fund } \\
\text { could for instance move gradually to become (...) an international central bank." }\end{array}$ \\
\hline $\begin{array}{l}\text { Crise } \\
\text { Financeira } \\
\text { Internacional }\end{array}$ & $\begin{array}{l}\text { - II/2011 "The deterioration of the outlook for advanced economies is to a large extent } \\
\text { caused by the legacies and unsolved problems of the } 2008 \text { financial crisis, including high } \\
\text { unemployment, especially among the young, the unfinished reform of the financial sector, } \\
\text { the incomplete repair of household balance sheets and, in many countries, weak housing } \\
\text { markets. These unsolved problems have combined with sovereign debt sustainability } \\
\text { concerns, notably in some euro area countries, to generate acute volatility in financial } \\
\text { markets and depress economic activity." } \\
\text { - II/2008 "The world economy has been brought to a critical situation. Our generation has never } \\
\text { seen such a deep crisis. Intense speculation in financial markets, lack of adequate regulation } \\
\text { and supervision, and weak crisis resolution mechanisms in important countries have led } \\
\text { to what seems to be by far the worst financial debacle since World War II. (..) The United } \\
\text { States and Europe are at the center of the financial storm. The world watches in disbelief as } \\
\text { the unfolding crisis reveals serious systemic weaknesses and policy blunders in what used } \\
\text { to be regarded as model countries, countries that were presented as references of good } \\
\text { governance, as examples to be imitated. The IMF itself used to take these countries' financial } \\
\text { systems as the basis for devising so-called best practices in terms of financial management." }\end{array}$ \\
\hline
\end{tabular}

13 Disponivel em: <http://www.imf.org/external/ns/search.aspx?NewQuery=mantega+imfc+statement\&filter_val=N\&col=SITENG \&collection=SITENG\&lan=eng\&f=>. Acesso em: 05 mar. 2013. 


\begin{tabular}{|c|c|}
\hline CATEGORIA & EXTRATOS DOS DISCURSOS DO MINISTRO DA FAZENDA NO IMFC \\
\hline $\begin{array}{l}\text { Desequilíbrios } \\
\text { Globais }\end{array}$ & $\begin{array}{l}\text { - I/2012 "We have doubts about the quality, consistency and evenhandedness of the ongoing } \\
\text { work on capital flow management and urge the Fund to rethink its approach." } \\
\text { - II/2010 "Unsynchronized monetary stances between advanced and emerging market } \\
\text { countries are leading to a massive shift of capital resources to the latter. These capital } \\
\text { movements are stimulated by the growth potential of emerging market countries, large } \\
\text { interest rate differentials, and open capital accounts. (...) The IMF is aware of the difficulties } \\
\text { faced by EMDCs in managing sizable and potentially volatile capital flows. (...) Despite this } \\
\text { acknowledgement, the Fund is still reluctant to draw practical conclusions from its analysis. } \\
\text { (...) Pragmatic policy recommendations on how to limit excessive short-term flows should } \\
\text { have more prominence in our deliberations and in the Fund's agenda." }\end{array}$ \\
\hline $\begin{array}{l}\text { Padrões } \\
\text { e Códigos } \\
\text { Financeiros } \\
\text { Internacionais }\end{array}$ & $\begin{array}{l}\text { - II/2011 "Persistently loose monetary policies in the reserve currency issuing countries have } \\
\text { done little to support their economic recovery but have caused considerable headaches for } \\
\text { emerging market countries that are forced to manage the international spillovers from these } \\
\text { policies." } \\
\text { - I/2008 "What is important now is to establish new systems to regulate and supervise } \\
\text { financial systems, as well as new codes of conduct for rating agencies. It is also necessary } \\
\text { to deal with the abuses and distortions in the pay and in the rather perverse system of } \\
\text { incentives faced by financial executives." }\end{array}$ \\
\hline $\begin{array}{l}\text { Reforma de } \\
\text { Quotas e } \\
\text { Covernança } \\
\text { do FMI }\end{array}$ & $\begin{array}{l}\text { - II/2012 "Despite our efforts, the } 2010 \text { quota and governance reforms did not enter into } \\
\text { force by the time of these Annual Meetings, as agreed by the membership in } 2010 \text { and } \\
\text { reiterated many times by the G20 and the IMFC. The failure to implement even limited } \\
\text { reforms, approved by an overwhelming majority of countries, sends a negative signal to } \\
\text { the outside world about the Fund's governance structure and its willingness to change. } \\
\text { Resistance to reform undermines the efforts to transform the IMF into a truly multilateral } \\
\text { and representative organization." } \\
\text { - II/2012 "G-20 Leaders have, in their Los Cabos summit in June this year, reiterated once again } \\
\text { "(...) that the distribution of quotas based on the formula should better reflect the relative } \\
\text { weights of IMF members in the world economy, which have changed substantially in view of } \\
\text { strong GDP growth in dynamic emerging markets and developing countries". Unfortunately, } \\
\text { we are witnessing since then attempts by some G-20 countries to backtrack on this and other } \\
\text { commitments." } \\
\text { - I/2009 "The IMF repented from many of its past sins. But it still has to address the original } \\
\text { sin: its democratic deficit. (...) The Fund's legitimacy depends on this." }\end{array}$ \\
\hline $\begin{array}{l}\text { Regulação } \\
\text { Financeira } \\
\text { Internacional }\end{array}$ & $\begin{array}{l}\text { - I/2008 "The current crisis revealed remarkable weaknesses and deficiencies in the financial } \\
\text { systems and regulatory structures of countries that were previously considered to be } \\
\text { examples the rest of the world should follow. The model in place until now was based largely } \\
\text { on the assumption that financial markets could self-protect and self-regulate. It was thought } \\
\text { that financial agents would basically be able to take care of themselves. What is important } \\
\text { now is to establish new systems to regulate and supervise financial systems (....." } \\
\text { - II/2007 "In developed countries, and in other countries too, there is a need to strengthen } \\
\text { the regulation of derivatives markets and to pay close attention to hedge funds. Much of } \\
\text { the fragility resides apparently in those speculative funds that are highly leveraged and not } \\
\text { subject to regulation and supervision. It does not seem to me that regulation of the financial } \\
\text { system as a whole, and of those sectors in particular, has received the attention it deserves } \\
\text { from the IMF." }\end{array}$ \\
\hline
\end{tabular}


Considerando que fica demonstrado que, primeiramente, cada um destes tópicos é de grande relevância para o Brasil e, adicionalmente, que o país tem claro interesse em avançar na discussão destes temas, entende-se que a instituição, dentre as duas analisadas neste trabalho - IMFC e G20 ministerial -, que garante mais espaço a estes tópicos, tanto em suas deliberações quanto em seus comunicados oficiais, apresenta maior conformidade em relação ao interesse brasileiro no que diz respeito à governança econômica global. De qualquer modo, tendo em vista uma abordagem qualitativa preliminar dos discursos do ministro da Fazenda no IMFC no período entre 2006 e 2012, a qual pode ser ilustrada pelos trechos de discursos acima dispostos, é possível perceber que, qualitativamente, o posicionamento oficial brasileiro apresenta, ao longo do período analisado, maior conformidade com a manifestação consensual divulgada pelo G20 do que com aquela divulgada pelo IMFC. ${ }^{14}$

Uma possivel objeção a este entendimento dá conta de que outros países também podem ter interesse na discussão dos mesmos temas - isto poderia inclusive ser um fator mais presente em uma das instituições, em função de seu conjunto de membros diferenciado, o que minimizaria o impacto da posição específica do Brasil quanto a determinado tema. Ocorre que, ainda que a influência dos diferentes países sobre os comunicados possa ser um objeto de pesquisa interessante, envolvendo a causalidade na geração do consenso no âmbito de instituições internacionais, a pesquisa ora apresentada possui outro foco, se referindo apenas às diferenças na conformidade de cada uma das instituições em relação ao posicionamento oficial do governo brasileiro.

Outra possivel observação a respeito da compreensão emitida acima seria a de que o Brasil não tem interesse simplesmente em observar maiores extensões de textos nos comunicados concernentes aos tópicos analisados; o país tem, na verdade, interesse em observar uma manifestação consensual que tenha maior conformidade com sua visão específica, a qual gere ações coordenadas compatíveis com esta visão, ainda que isto signifique textos dedicados a estes temas menos extensos nos comunicados. Entretanto, se considerarmos o histórico recente do modelo de negociações no sistema internacional, calcado em uma concepção tradicional de ordem global, é possível compreender que o avanço nas discussões, entendido como a dedicação de mais espaço na discussão a respeito de um tema caro às economias emergentes e, ao mesmo tempo, pouco popular entre as economias avançadas, é entendido, em si mesmo, como um avanço na busca de um novo equilíbrio nesta ordem global.

Como se pode observar pelos trechos de discurso selecionados, a posição brasileira é crítica com relação a muitos pontos que vão diretamente de encontro às políticas dos países mais industrializados, como, por exemplo, a denúncia da política monetária expansionista destes países e seus efeitos sobre os emergentes, a necessidade de mais regulação financeira, entre outros aspectos. Em um destes discursos surgiu o conceito de "guerra cambial" (currency war), criado pelo ministro Guido Mantega e posteriormente integrado ao debate internacional.

14 Frequentemente o ministro da Fazenda cita, em seus discursos no IMFC, trechos dos comunicados oficiais do G20 para fundamentar suas posições. 


\section{Apresentação e análise dos resultados obtidos a partir da análise empírica}

As posições do governo brasileiro consolidadas, como mencionado acima, serviram como material para a análise quantitativa de dados textuais ${ }^{15}$ que comparou os documentos divulgados pelos dois organismos. A seguir apresentamos os resultados.

\section{Caracteristicas gerais dos comunicados oficiais}

Inicialmente, são apresentadas as informações referentes à extensão do texto e à evolução dos temas nos communiqués emitidos pelo IMFC e pelo G20 ministerial no período 2006-2012.16

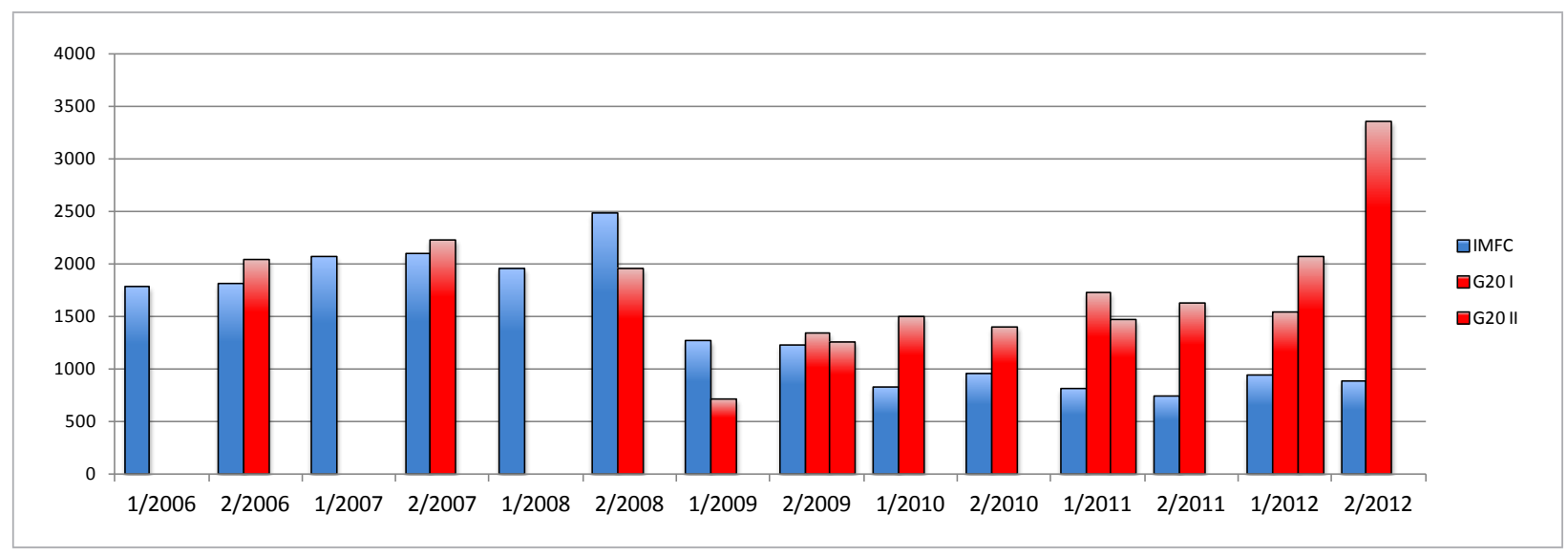

Gráfico 1 - Extensão do texto em palavras dos communiqués do IMFC e do G20 no período 2006-2012

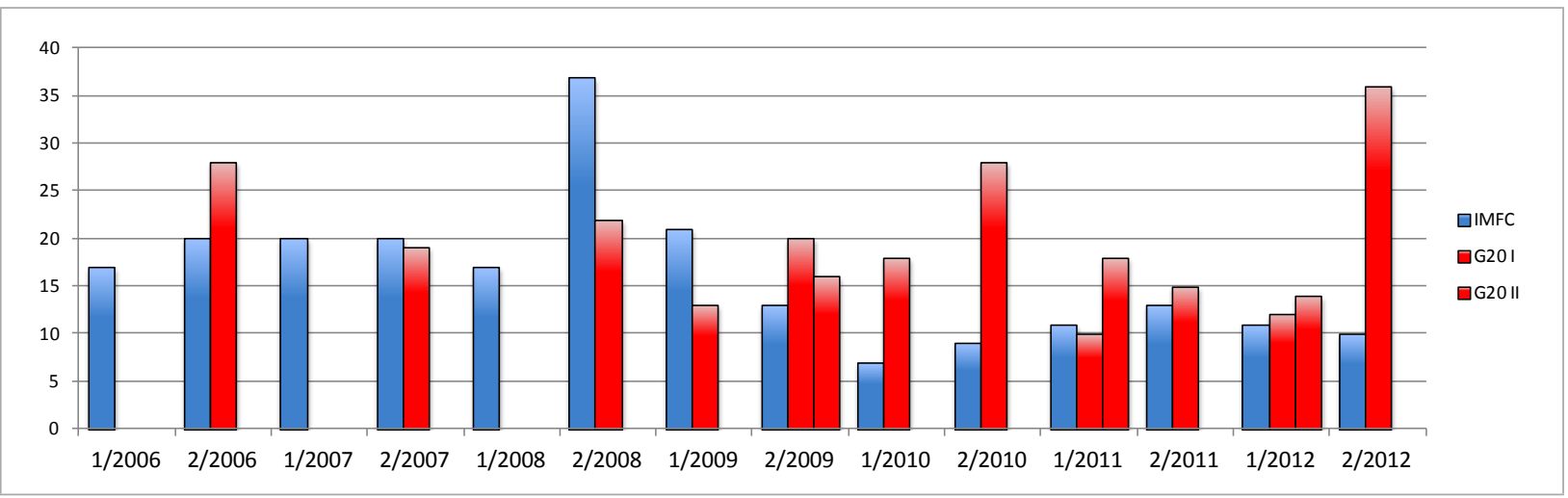

Gráfico 2 - Extensão do texto em parágrafos dos communiqués do IMFC e do G20 no período 2006-2012

15 É importante destacar que na análise quantitativa foram considerados os comunicados oficiais do IMFC e do G20 ministerial pelo fato de ambos representarem o consenso estabelecido nos respectivos encontros - conforme mencionado anteriormente, os discursos do ministro da Fazenda não foram incluídos na análise quantitativa por não representarem um consenso, mas um comentário destinado a influenciar a formação do consenso.

16 Cabe lembrar, como já observado e indicado nos gráficos que, em três dos semestres analisados, o G20 ministerial não emitiu nenhum communiqué ( $1^{\circ}$ semestre de 2006, $1^{\circ}$ semestre de 2007 e $1^{\circ}$ semestre de 2008); em compensação, em outros três semestres o G20 ministerial emitiu dois communiqués. Finalmente, vale recordar que foram incluídos no cômputo geral os anexos referentes a temas específicos da governança econômica global (no caso do IMFC, no $2^{\circ}$ semestre de 2008; no caso do G20, no $2^{\circ}$ semestre de 2009). 


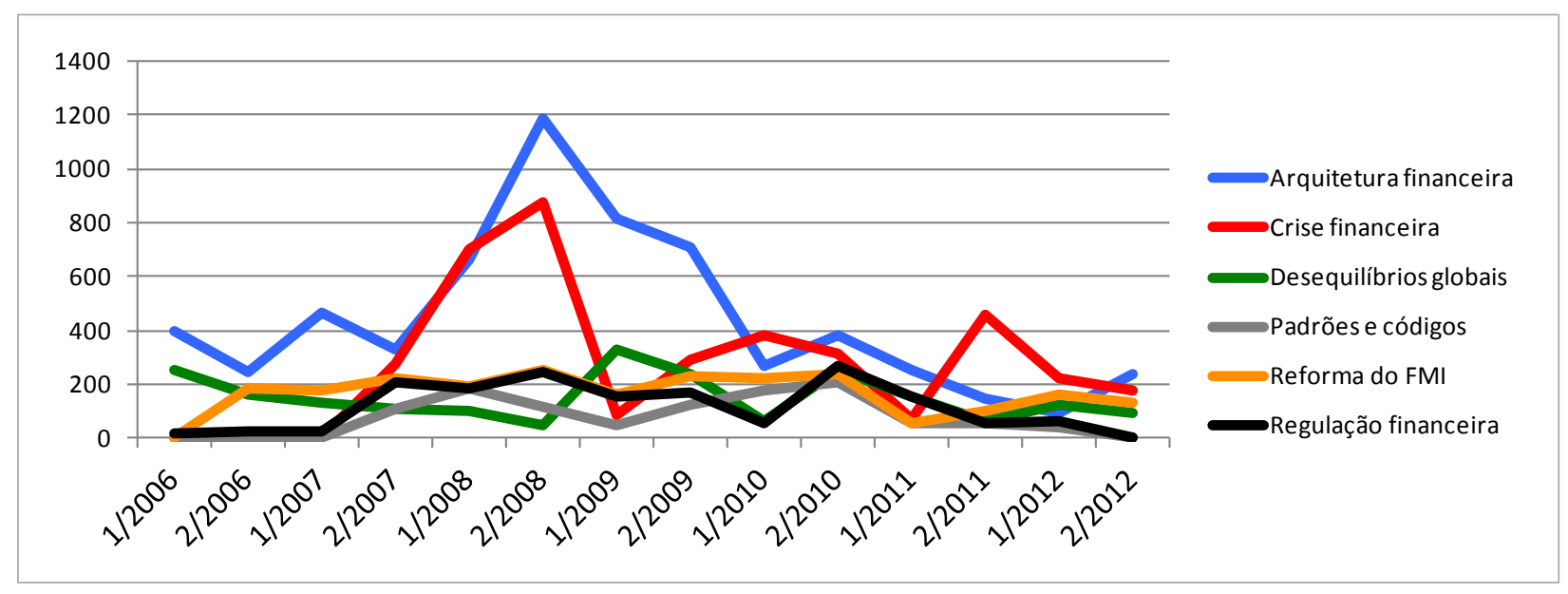

Gráfico 3 - Evolução do total de palavras por tema nos communiqués do IMFC no período 2006-2012

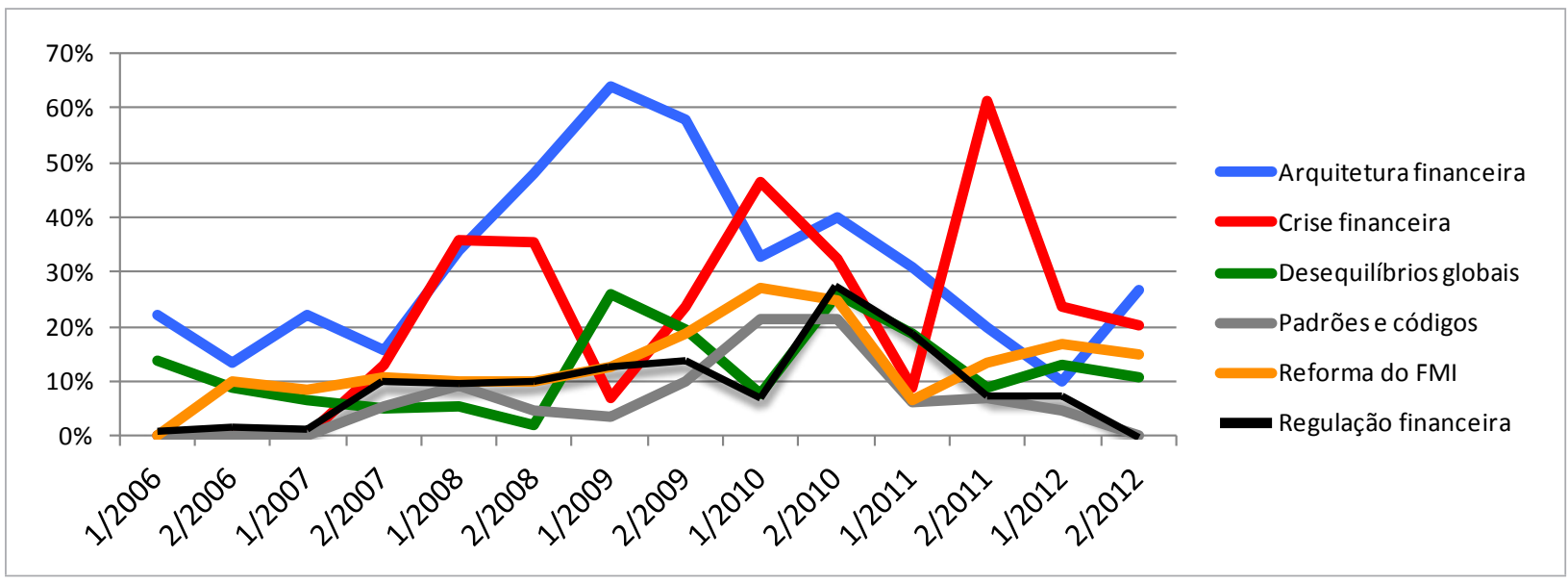

Gráfico 4 - Evolução percentual dos temas dos communiqués do IMFC no período 2006-2012

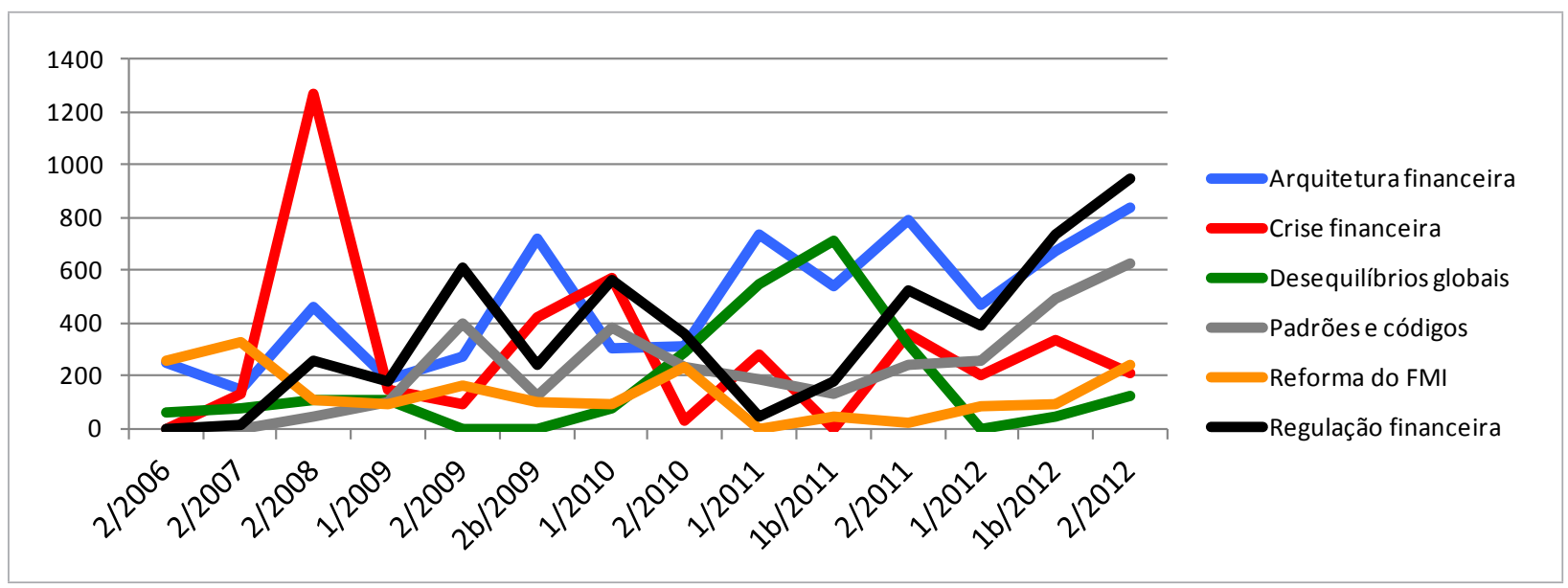

Gráfico 5 - Evolução do total de palavras por tema nos communiqués do G20 no período 2006-2012 


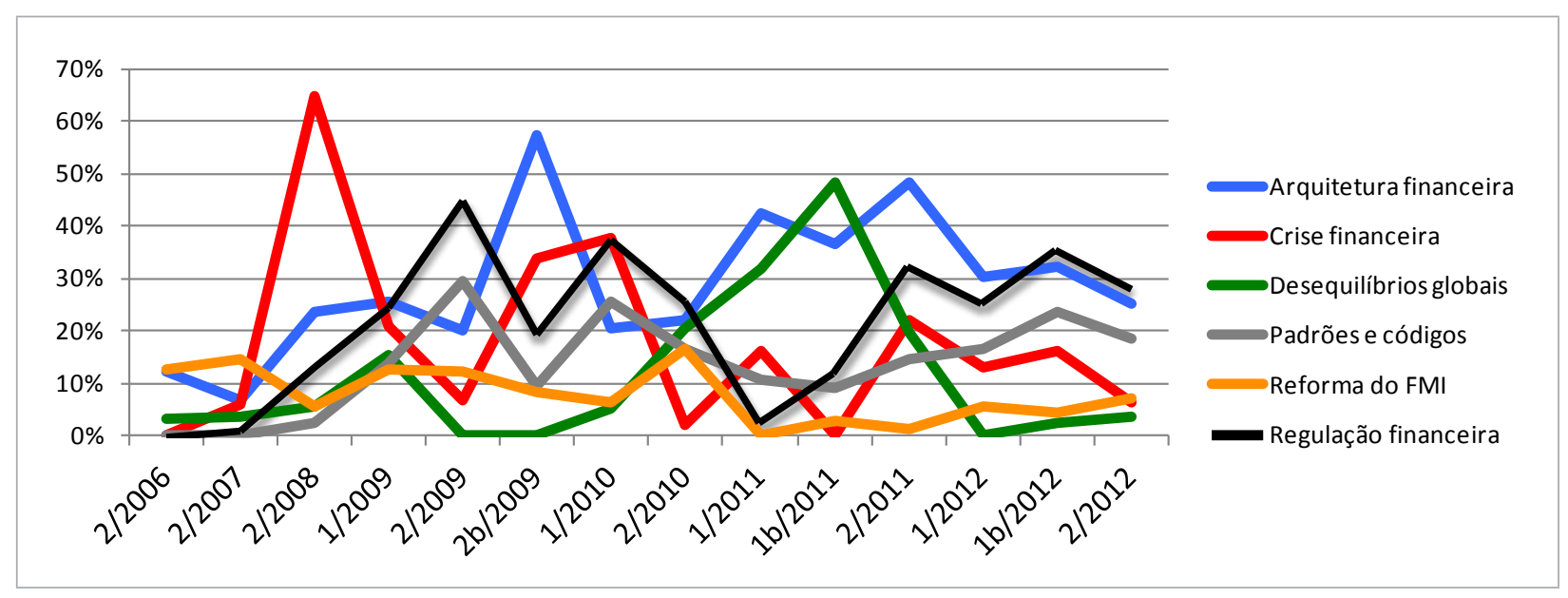

Gráfico 6 - Evolução percentual dos temas dos communiqués do G20 no período 2006-2012

\section{Categoria de análise "Arquitetura Financeira Internacional"}

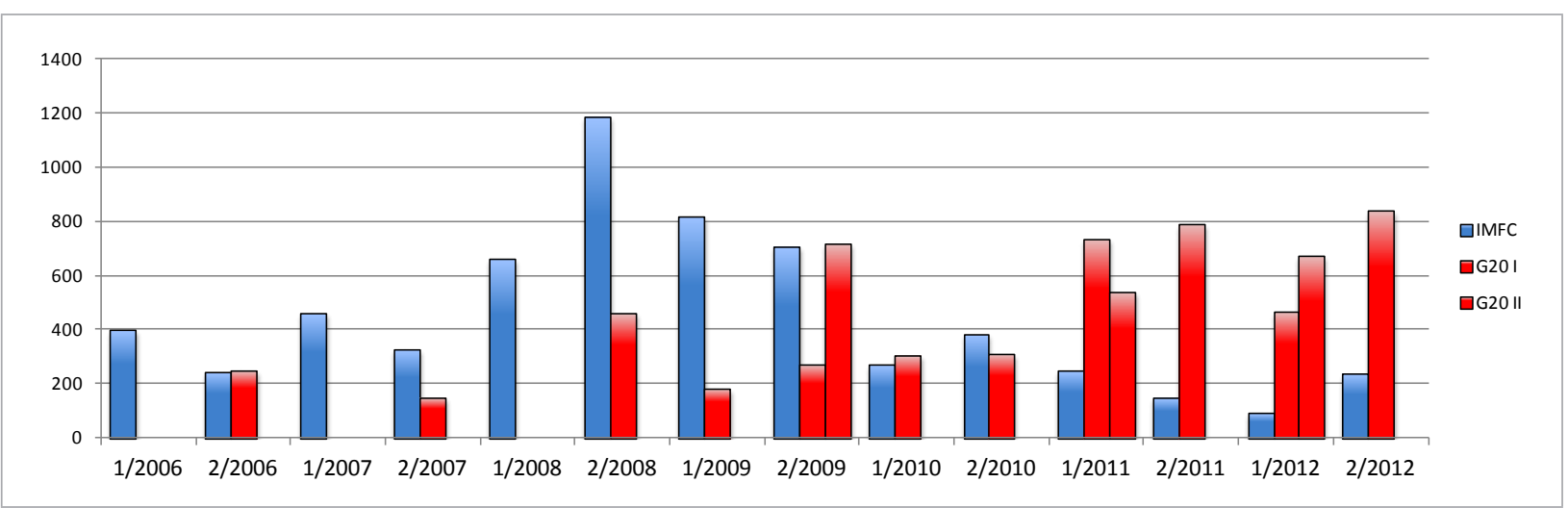

Gráfico 7 - Extensão em número de palavras da categoria Arquitetura Financeira Internacional nos communiqués do IMFC e do G20 no período 2006-2012

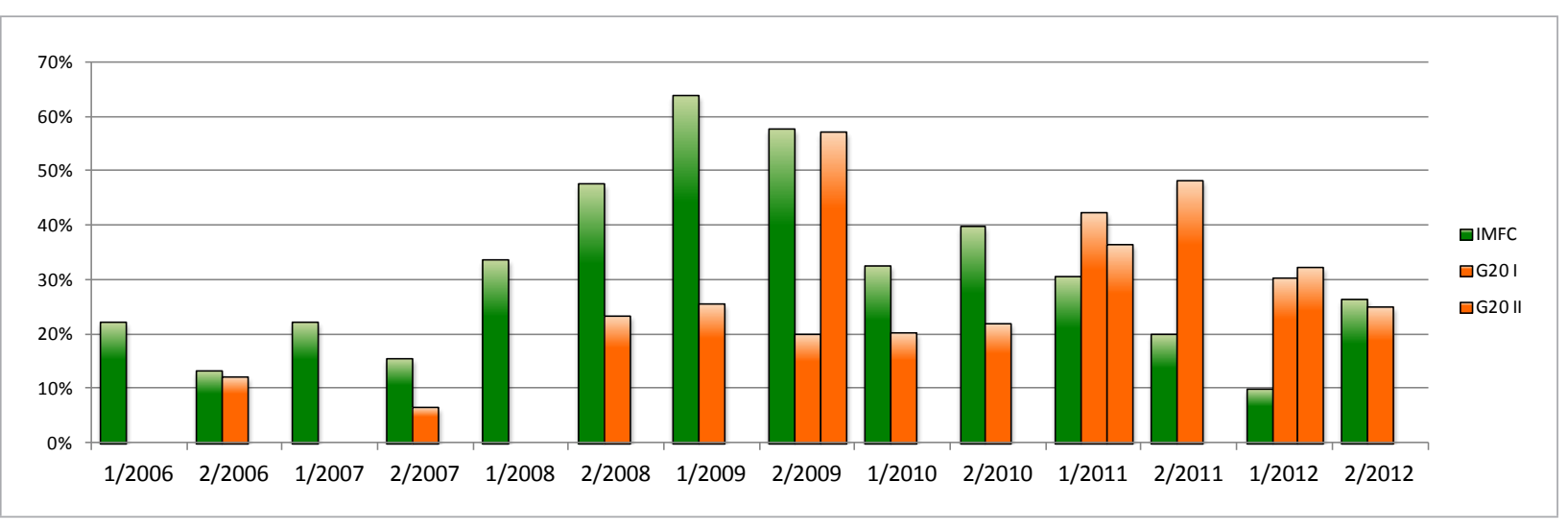

Gráfico 8 - Distribuição percentual da categoria Arquitetura Financeira Internacional nos communiqués do IMFC e do G20 no período 2006-2012 
Na categoria Arquitetura Financeira Internacional, os dados obtidos demonstram que o tema das operações das instituições financeiras internacionais, bem como da revisão de atribuições e responsabilidades das instituições internacionais responsáveis pela gestão da governança econômica global esteve, ao longo de todo o período analisado, entre os principais temas abordados nos comunicados oficiais do IMFC, o que é observado tanto em termos da extensão dos textos dedicados ao tema (média de 442,3 palavras) quanto do percentual do documento que trata de assuntos vinculados a esta categoria (média de 31,3\%). Em ambos os casos, no IMFC e no G20 ministerial, esta categoria teve grande relevância no período, mas, enquanto o ponto alto da atenção ao tema nos comunicados do IMFC coincide com o auge da crise financeira internacional, no G20 ministerial os assuntos ligados à arquitetura financeira internacional continuam crescendo em importância nos comunicados divulgados - fato este que, por sua vez, apresenta maior conformidade com o posicionamento brasileiro a respeito do tema, que enfatiza tanto o contínuo aprimoramento das operações e atividades das instituições financeiras internacionais quanto à modernização da arquitetura financeira internacional.

\section{Categoria de análise "Crise Financeira Internacional"}

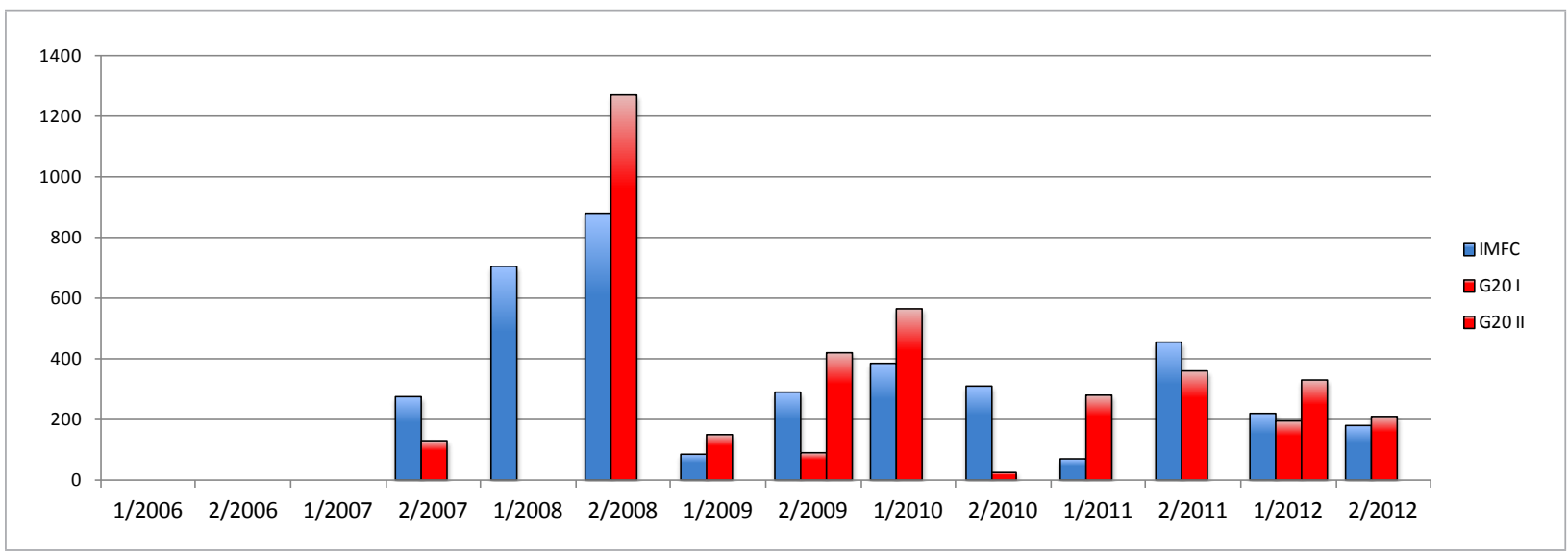

Gráfico 9 - Extensão em número de palavras da categoria Crise Financeira Internacional nos communiqués do IMFC e do G20 no período 2006-2012

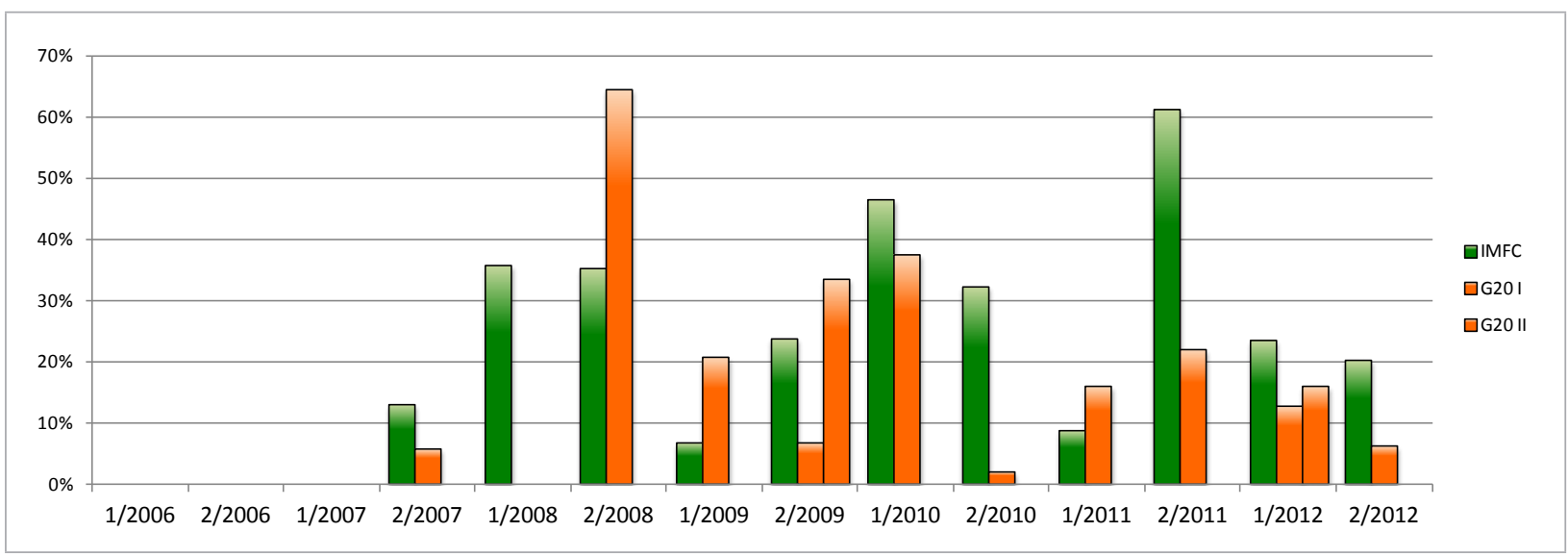

Gráfico 10 - Distribuição percentual da categoria Crise Financeira Internacional nos communiqués do IMFC e do G20 no período 2006-2012 
Na categoria Crise Financeira Internacional é possível observar que, no caso do IMFC, o tema domina percentualmente os comunicados dos anos de 2008 e de 2010, auges da crise financeira e da dívida soberana europeia respectivamente, ainda que neste último caso em um nível menos expressivo, além de monopolizar o comunicado do segundo semestre de 2011, período dos resgates financeiros aos países europeus mais ameaçados pela crise. Este desempenho irregular também é observado nos comunicados do G20 ministerial, em que a categoria apresenta um grande pico no auge da crise, seguido de uma sequência inconstante e de baixa ênfase, sem permanecer entre os principais temas até o início de 2010, quando a crise da divida soberana europeia se espalha definitivamente. Em ambos os casos, a categoria apresenta niveis mais modestos nas reuniões mais recentes, mas o G20 ministerial tem dispensado mais espaço ao tema do que o IMFC - este fato também parece apresentar maior conformidade com o posicionamento brasileiro, uma vez que ambos os vértices da crise, bancária e da dívida, foram deflagrados em economias avançadas, sendo do interesse dos países emergentes que o assunto seja dissecado de forma a que sejam identificadas vulnerabilidades e responsabilidades, e que sejam asseguradas políticas efetivas para a resolução definitiva da turbulência.

\section{Categoria de análise "Desequilibrios Clobais"}

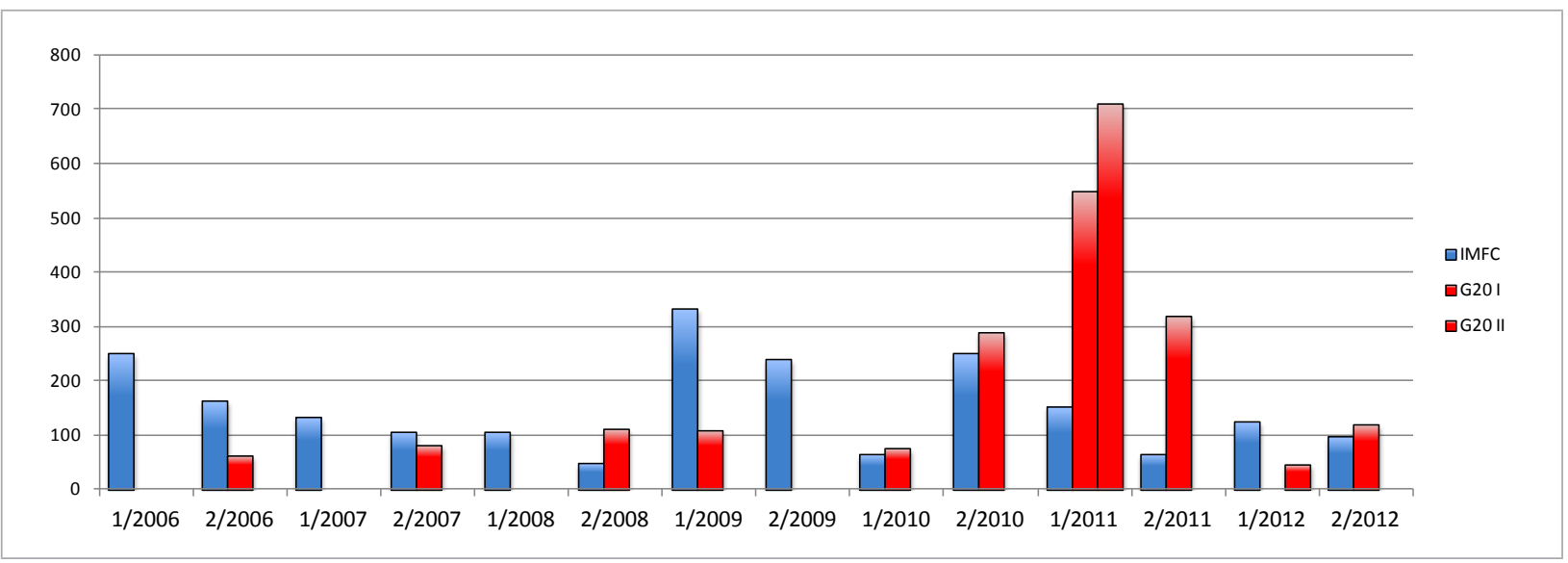

Gráfico 11 - Extensão em número de palavras da categoria Desequilíbrios Globais nos communiqués do IMFC e do G20 no período 2006-2012

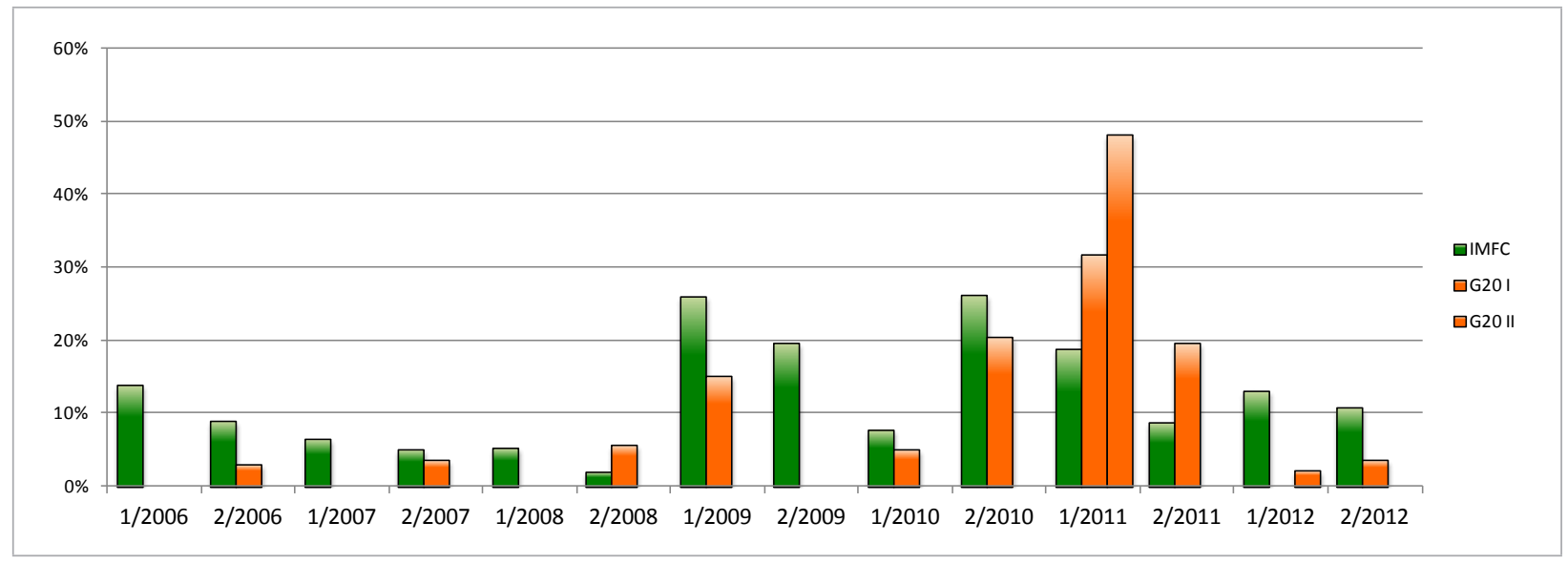

Gráfico 12 - Distribuição percentual da categoria Desequilíbrios Globais

nos communiqués do IMFC e do G20 no período 2006-2012 
Na categoria Desequilíbrios Globais é possivel observar que, após o tema ter sido amplamente considerado pelo IMFC antes do estouro da crise financeira internacional, o assunto perdeu importância diante da premência dos outros temas considerados neste estudo, dispondo de pouco espaço tanto no IMFC quanto no G20 ministerial. Este quadro permanece até que, ao longo do ano de 2011, o tema dos desequilíbrios globais é elevado ao topo nas reuniões do G20, aparecendo em primeiro lugar dentre as categorias aqui analisadas tanto em relação à extensão dos textos quanto ao percentual dos comunicados dedicados ao assunto, enquanto cresciam as divergências de opinião entre as economias avançadas a respeito da melhor maneira de lançar mão da política fiscal - uma vez que a política monetária havia chegado ao limite de sua margem de manobra -, o que pode ter deixado espaço para o resgate de um tema que contava com uma visão mais amplamente compartilhada: o fato de que os desequilíbrios globais precisam ser reduzidos de ambos os lados, envolvendo medidas sérias tanto nos países deficitários quanto nos superavitários. Esta ênfase do G20 no assunto, não acompanhada pelo IMFC, apresenta maior conformidade com o posicionamento brasileiro a respeito do tema, o qual considera que as maiores economias do mundo, avançadas e emergentes, devem implementar políticas que visem reduzir os desequilíbrios globais de forma a reduzir, inclusive, a ameaça representada pela volatilidade de volumosos fluxos de capital que abalou economias emergentes e deu origem a um comportamento defensivo das mesmas por meio da acumulação de reservas internacionais.

\section{Categoria de análise "Padrões e Códigos Financeiros Internacionais"}

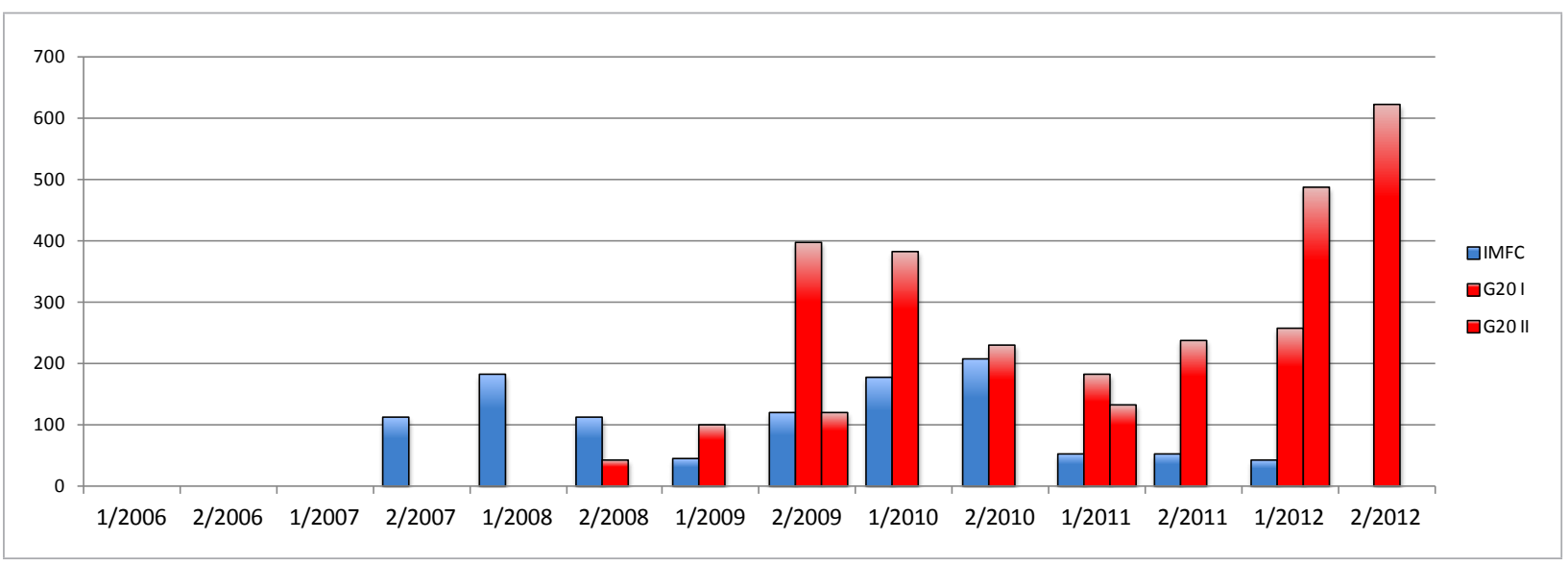

Gráfico 13 - Extensão em número de palavras da categoria Padrões e Códigos Financeiros Internacionais nos communiqués do IMFC e do G20 no período 2006-2012 


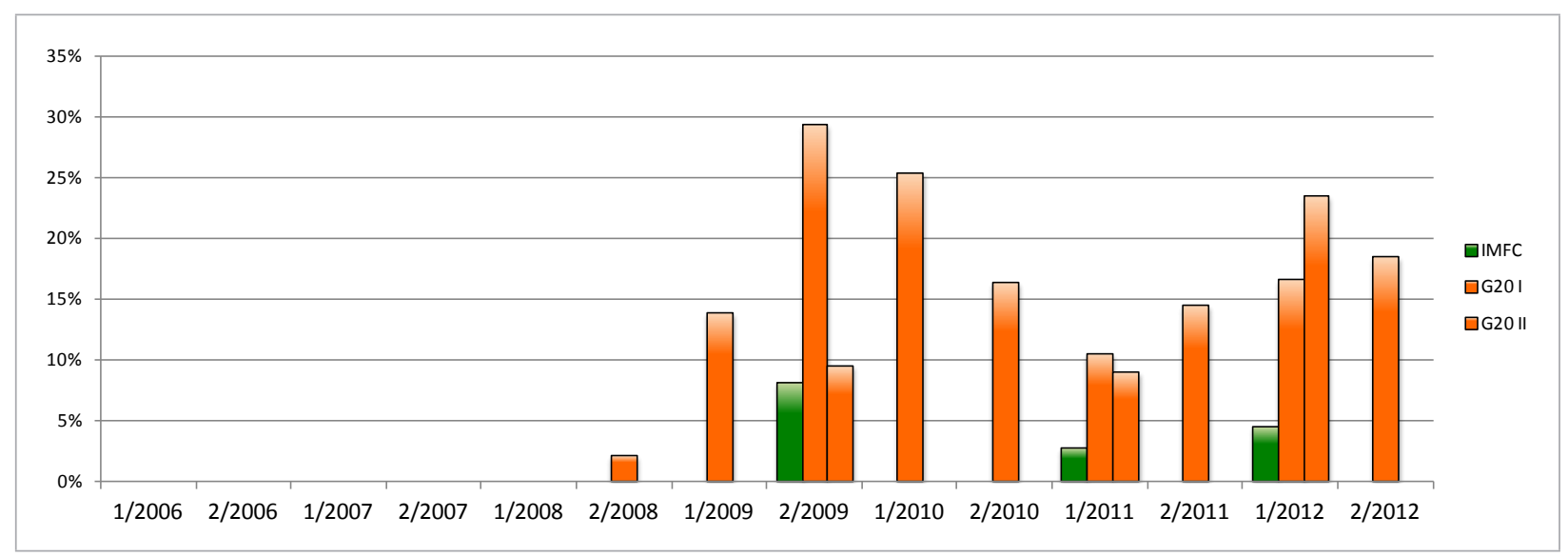

Gráfico 14 - Distribuição percentual da categoria Padrões e Códigos Financeiros Internacionais nos communiqués do IMFC e do G20 no período 2006-2012

Na categoria Padrões e Códigos Financeiros Internacionais observa-se a pouca ênfase que o tema recebeu nos comunicados do IMFC ao longo de todo o período analisado, especialmente ao ser considerada a relevância relativa por meio do percentual dos comunicados dedicados aos assuntos vinculados à categoria, apresentando um leve aumento no ano de 2010 e praticamente desaparecendo nos comunicados mais recentes. Ao mesmo tempo, o G20 ministerial vem dispensando maior espaço em seus comunicados ao tema, em ritmo crescente cujo pico é observado justamente no período mais recente do estudo. Este dado aponta para o engajamento maior do G20 na questão crucial da definição de padrões e códigos financeiros internacionalmente acordados, incluindo elementos de regulação financeira e da definição de políticas para a inclusão financeira. Esta tendência do G20 de dar maior atenção a este tema apresenta maior conformidade com o posicionamento do governo brasileiro, que se manifesta por uma regulação financeira internacional mais estrita e pela aprovação de políticas coordenadas que promovam a inclusão financeira, especialmente nos países em desenvolvimento.

\section{Categoria de análise "Reforma de Quotas e Governança do FMI"}

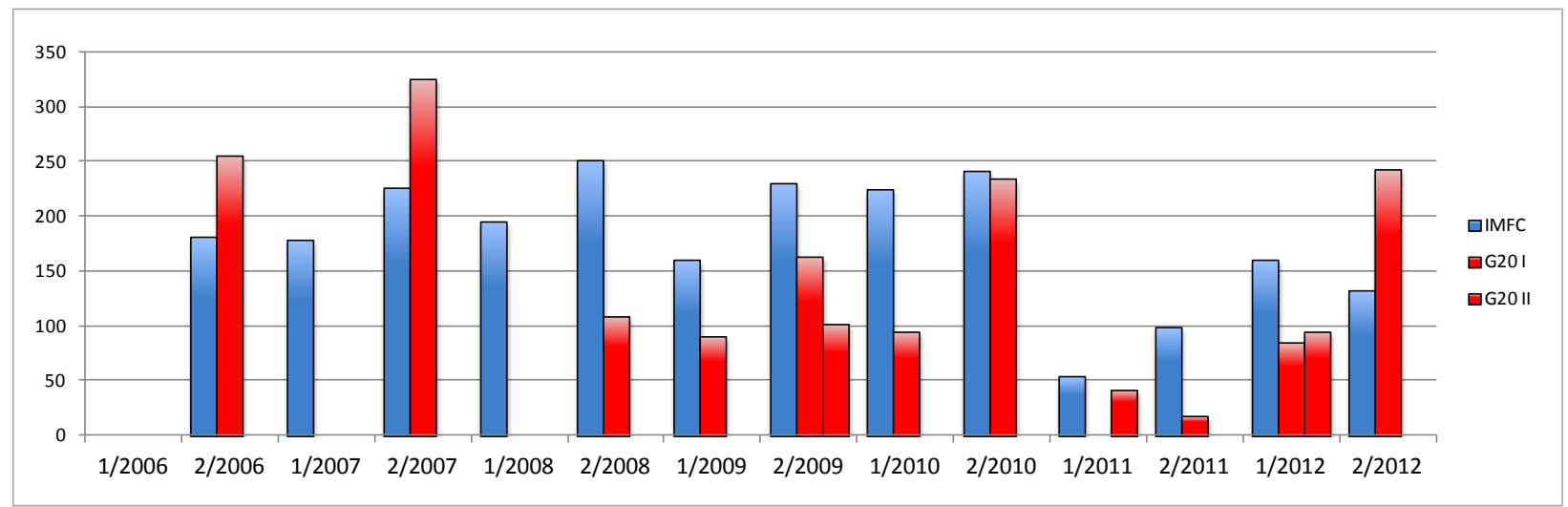

Gráfico 15 - Extensão em número de palavras da categoria Reforma de Quotas e Governança do FMI nos communiqués do IMFC e do G20 no período 2006-2012 


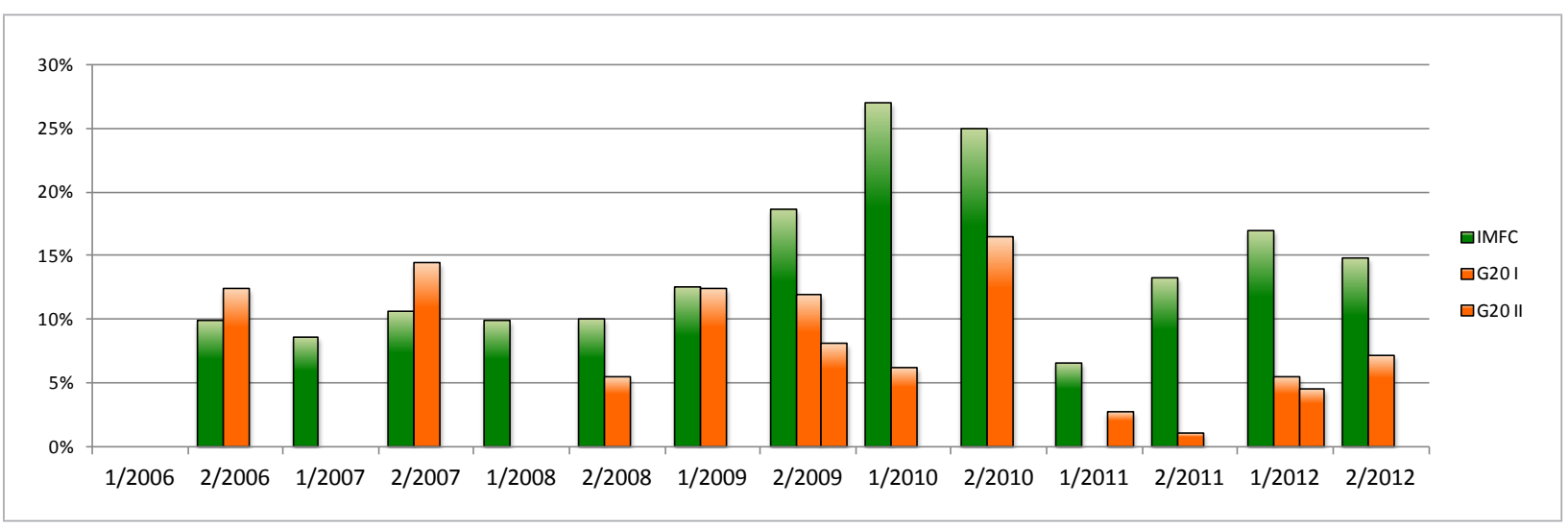

Gráfico 16 - Distribuição percentual da categoria Reforma de Quotas e Governança do FMI nos communiqués do IMFC e do G20 no período 2006-2012

Na categoria Reforma de Quotas e Governança do FMI, chama a atenção o pouco espaço dedicado ao tema em ambas as instituições ao longo de todo o período analisado - a categoria nunca está entre aquelas mais enfatizadas dentre as analisadas neste estudo em nenhum dos comunicados pesquisados. O IMFC apresentou um nivel constante de dedicação ao tema em seus comunicados até a resolução do impasse entre economias emergentes e avançadas no ano de 2010 (média de 166,8 palavras) - desde então o assunto praticamente desaparece dos comunicados oficiais. O G20, interessantemente, garantia mais espaço ao tema em seus comunicados antes da eclosão da crise financeira internacional, preterindo a ênfase sobre o assunto da reforma do FMI durante o auge da crise (média de 150,8 palavras). 0 pico observado em 2010 nos comunicados do G20, por ocasião da resolução do impasse mencionado, é seguido pelo abandono do tema até o final de 2012, quando a implementação da última reforma de quotas do FMI e a revisão da fórmula de cálculo das quotas voltam a receber mais espaço do que o tema dispõe nos comunicados do IMFC. O tema da reforma de quotas e governança do FMI é de grande interesse das economias emergentes em geral e do Brasil em particular, de forma que o pouco espaço garantido ao assunto nos comunicados oficiais de ambas as instituições não se encontra em conformidade com o posicionamento brasileiro de enfatizar a importância e a urgência da referida reforma. De qualquer forma, a leve retomada do tema, em especial em referência à revisão da fórmula de cálculo das quotas do FMI, promovida pelo G20 ministerial está em maior conformidade com o posicionamento brasileiro que tem destacado amplamente a importância desta reforma. 


\section{Categoria de análise "Regulação Financeira Internacional"}

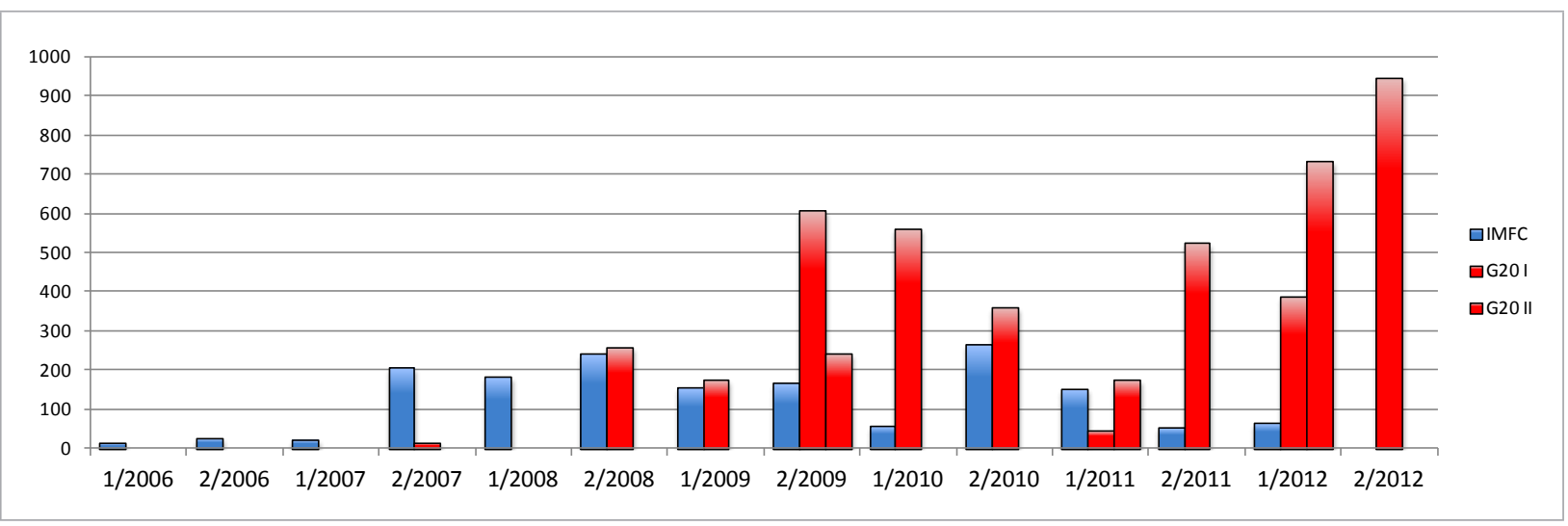

Gráfico 17 - Extensão em número de palavras da categoria Regulação Financeira Internacional nos communiqués do IMFC e do G20 no período 2006-2012

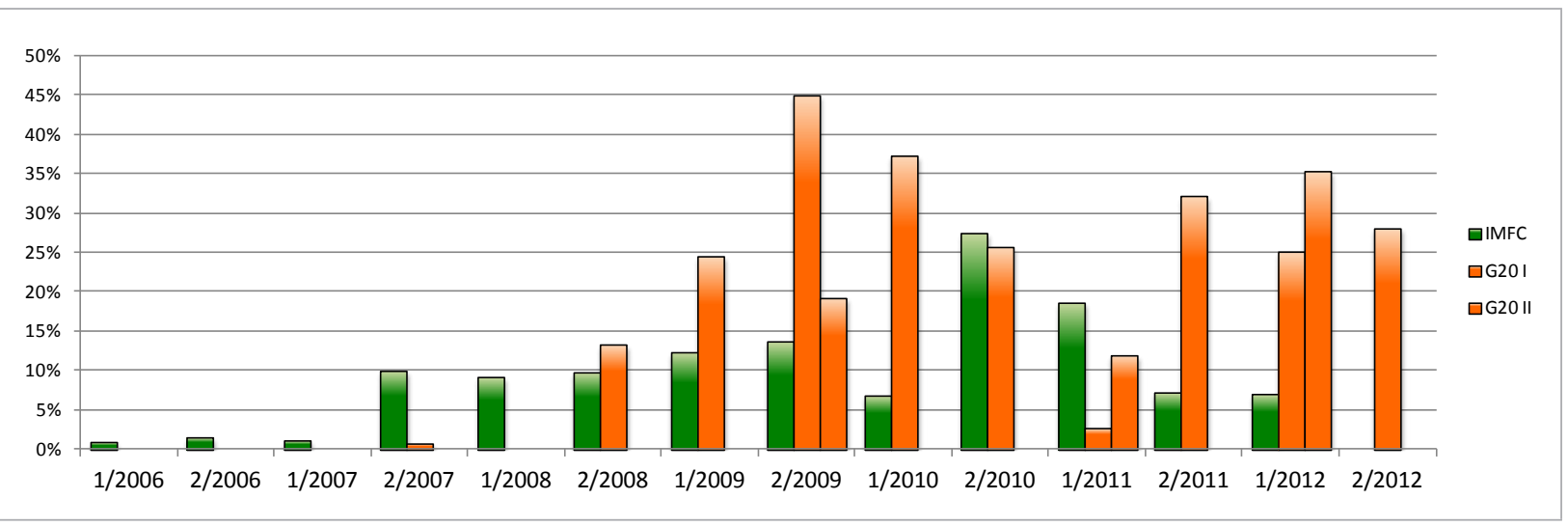

Gráfico 18 - Distribuição percentual da categoria Regulação Financeira Internacional nos communiqués do IMFC e do G20 no período 2006-2012

Na categoria Regulação Financeira Internacional é possivel observar uma diferença de abordagem entre as duas instituições internacionais. De um lado, o IMFC, ainda que tenha constantemente abordado o tema, dispensou espaço reduzido à categoria, apesar do pico de 2010, desde a eclosão da crise até o ano de 2011, quando o assunto praticamente desaparece de seus comunicados. Por outro lado, no G20 ministerial o tema recebeu espaço percentual praticamente estável dentro dos comunicados, mas com um aumento constante na extensão dos textos dedicados à categoria da regulação financeira internacional, incluindo os maiores picos da série no ano de 2012. Considerando a relevância estratégica do tema para a governança financeira global, e considerando a ênfase dada pelas economias emergentes quanto à importância da reforma do setor financeiro internacional e da revisão da regulação financeira internacional, a atenção crescente dispensada pelo G20 ao tema está em maior conformidade com o posicionamento brasileiro, que defende a regulação financeira como instrumento de controle dos excessos financeiros e proteção aos cidadãos. 
Da análise comparativa feita para cada categoria, verificamos que os communiqués do G20 se aproximam mais dos temas considerados mais importantes pelo discurso oficial brasileiro do que os documentos de consenso emitidos pelo IMFC. Isto permite confirmar a hipótese inicial de trabalho segundo a qual os comunicados do G20 apresentam maior conformidade com o posicionamento do governo brasileiro. Fatores institucionais corroboram esta observação. Por ser uma rede de países não formalizada, o G20 tem mais flexibilidade para inserir temas na agenda de discussões - e, portanto, pode refletir melhor os acontecimentos - e assumir posições. A não existência de pesos diferenciados para os países membros amplia, em termos relativos, o espaço político dos emergentes.

\section{Verificação de confiabilidade da análise empírica}

Os resultados da análise empírica apresentada até aqui passaram por uma verificação da confiabilidade com o suporte da metodologia de análise quantitativa de dados textuais clássica. Deste modo, foram empregadas ferramentas informatizadas de quantitative textual analysis, capazes de extrair dados quantitativos de uma sequência de textos como a utilizada neste estudo. Para este fim, todo o material analisado neste trabalho - ou seja, os mesmos 28 communiqués, sendo 14 comunicados referentes a reuniões do IMFC e 14 comunicados referentes a reuniões do G20 ministerial, emitidos no período de 2006 a 2012 - foi inserido no programa ODA Miner, de tratamento de base de dados. Em seguida, utilizando a ferramenta Wordstat, foram extraídas estatísticas relativas às quantidades e proporções das palavras utilizadas em cada comunicado considerado. A partir da construção de dicionários correspondentes às mesmas categorias de análise definidas pelo G20 Research Group utilizadas na etapa anterior deste estudo - por meio da seleção de palavras-chave estritamente vinculadas a cada uma das seis categorias, ${ }^{17}$ foi possível identificar as distribuições relativas entre as categorias em cada uma das instituições ao longo do período analisado.

O novo exercício confirmou os resultados obtidos por meio da aplicação de técnicas de análise quantitativa de dados textuais clássica - como redução da extensão dos comunicados oficiais do IMFC e aumento da extensão dos comunicados oficiais do G20 ministerial, tendência de aumento crescente na ênfase do G20 sobre as categorias Arquitetura Financeira Internacional, Reforma de Quotas e Governança do FMI e Regulação Financeira Internacional, tendência de redução na ênfase do IMFC sobre as categorias Arquitetura Financeira Internacional, Desequilíbrios Globais e, em menor escala, Reforma de Quotas e Governança do FMI.

\section{Natureza das instituições}

A análise dos resultados empíricos deve considerar, ademais, fatores referentes às funções e características das instituições que se procurou estudar. Antes de tudo, se pode confrontar os

\footnotetext{
17 Palavras-chave vinculadas às categorias de análise: Arquitetura Financeira Internacional - arrangements, capacity, concessional, facilities, fund, institutions, leaders, stability, surveillance, IMF; Crise Financeira Internacional - challenges, confidence, crisis, recovery, risk, risks, spillover, systemic, volatility, vulnerabilities; Desequilíbrios Globais - euro, flow, imbalances, Japan, states, united; Padrões e Códigos Financeiros Internacionais - standards; Reforma de Quotas e Governança do FMI - formula, governance, IEO, quota, quotas, reform, reforms, voice; Regulação Financeira Internacional - derivatives, FSB, inclusion, oversight, regulation, resilience, sound, strengthen, strengthening, system.
} 
objetivos iniciais do G20 e do IMFC, encontrando aí vocações mais precisas para as categorias de análise selecionadas. Assim, o G20, nascido nas crises financeiras da década de 1999, teria um papel mais afeito à regulação financeira internacional, tema que vincula várias das categorias utilizadas no estudo, enquanto que o IMFC teria um papel mais operacional. Mas este não parece ser um fator limitante. A questão que permite a análise comparativa é o fato de que o IMFC se permite tratar e divulgar suas posições a respeito dos diversos temas aqui analisados referentes à governança econômica global mesmo após a emergência do G20 ao patamar de principal fórum de cooperação econômica internacional. Deste modo, conforme visto acima, eventuais diferenças no peso dado a determinados assuntos nos comunicados oficiais destas instituições da governança econômica global - em função de suas diferenças históricas, estruturais e de governança institucional - não devem passar despercebidas.

Outra reflexão originada por esta análise diz respeito a uma eventual contraposição dos dados empíricos com o quadro de referência do posicionamento oficial do governo brasileiro em relação aos temas da governança econômica global. Segundo este raciocínio, seria possível imaginar que não só o Brasil, mas também outras economias emergentes - como se espera - e, até mesmo, algumas dentre as economias avançadas podem vir a compor, por meio de suas manifestações formais públicas, um quadro de posicionamentos oficiais bastante similar àquele considerado neste estudo - logo, se uma economia avançada manifesta posicionamentos semelhantes aos brasileiros, o isolamento da posição brasileira como parâmetro de avaliação só teria validade se contraposto ao posicionamento oficial de outro país que se mostrasse claramente distinto. Entretanto, o que se investigou aqui foram as diferenças nas variações na conformidade do posicionamento oficial de duas das principais instituições internacionais da governança econômica global, extraído a partir dos comunicados oficiais emitidos após seus encontros ministeriais, em relação à posição manifesta formalmente por um único país emergente, o Brasil, ao longo do tempo.

Deste modo, é possivel observar diferenças importantes no tratamento que cada uma destas instituições concede aos mesmos temas, no mesmo período, bem como eventuais tendências de cada uma delas de se aproximar ou se distanciar da visão defendida por uma economia emergente como o Brasil - independentemente de posições específicas na agenda.

Não pretendemos afirmar que um país emergente tenha atuado no período como agenda setter. Embora o estudo não tenha buscado identificar relações de causalidade, entende-se que a tomada de posição de um país, as propostas ou repetições de determinados temas ou argumentos em fóruns multilaterais têm efeitos sobre o espaço político que ocupa e, eventualmente, podem dar início a uma disseminação destas ideias e discussão mais ampla.

\section{Conclusão}

As semelhanças e diferenças na conformidade entre o posicionamento oficial do governo brasileiro e o consenso expresso após as reuniões do FMI e do G20 foram investigadas aqui por meio da aplicação da análise quantitativa de dados textuais clássica. Esta análise permitiu a identificação de uma redução na extensão dos communiqués do IMFC, ao mesmo tempo em que 
se observou um aumento na extensão dos communiqués do G20, o que aponta para um ganho de relevância deste último em um contexto de busca de soluções para problemas aprofundados pela crise financeira internacional, em detrimento do primeiro.

Isto é confirmado pela análise das categorias temáticas, que mostra uma ênfase maior em questões emergidas no pós-crise, mesmo se não diretamente tratando da crise. Assim, observa-se um aumento no espaço dedicado pelo C20 aos temas relacionados à Arquitetura Financeira Internacional, aos Desequilíbrios Globais, aos Padrões e Códigos Financeiros Internacionais e, especialmente, à Regulação Financeira Internacional - ao mesmo tempo em que se verifica um declínio no espaço dedicado aos mesmos temas nos communiqués do IMFC. As categorias relacionadas à Crise Financeira Internacional propriamente e à Reforma de Quotas e Governança do FMI apresentam resultados menos conclusivos. A posterior aplicação de recursos de análise quantitativa de dados textuais informatizada, a partir da construção de dicionários de palavras-chave, confirmou as tendências observadas na etapa anterior da análise empírica. A observação destes resultados a partir da aplicação de uma segunda metodologia reforça o aspecto da confiabilidade da pesquisa.

Os resultados do estudo dão sustentação ao fenômeno extensamente discutido na literatura de economia política internacional desde a crise asiática de 1997: uma necessidade de reformulação da estrutura de governança do FMI de forma a ampliar voz e voto dos países emergentes (DESAI e VREELAND, 2011; EICHENGREEN, 2009; WOODS, 2010a; i.a.). Um organismo como o G20, mesmo sem poder deliberativo, oferece o espaço e a flexibilidade para os países emergentes se posicionarem (WOODS, 2010b). O Financial Stability Board (FSB), sucessor do Financial Stability Forum, criado no âmbito do G20, tem sido um canal para uma efetiva discussão de reformas financeiras internacionais, debate institucionalmente improvável (ou inviável) nos encontros regulares do Fundo.

A presença do Brasil em fóruns de governança financeira global foi particularmente marcante entre 2006 e 2012. O país defendeu, em várias ocasiões, posições contrárias às políticas que estavam sendo implementadas pelos países avançados, especialmente a política monetária norte-americana. A denúncia da existência de uma guerra cambial justificou, de certo modo, frente à comunidade internacional, a imposição de controles de capital por parte do Brasil.

Em suma, considerando o posicionamento oficial do governo brasileiro, conforme formalizado nos discursos do ministro da Fazenda no IMFC, do qual é possível depreender o interesse em ampliar e aprofundar o debate a respeito dos temas vinculados às categorias analisadas, é possivel afirmar que o consenso expresso pelo G20 ministerial apresenta maior conformidade com a posição do Brasil do que aquele expresso pelo IMFC.

\section{Referências}

CHIN, G. 2010. Remaking the Architecture: The Emerging Powers, Self-insuring and Regional Insulation. International Affairs, 86(3): p. 693-715.

DESAI, R.; VREELAND, J. 2011. Global Governance in a Multipolar World: The Case for Regional Monetary Funds. International Studies Review, 13, p. 109-121. doi: 10.1111/j.1468-2486.2010.01002.x 
EICHENGREEN, B. 2009. Out of the Box Thoughts about the International Financial Architecture. IMF Working Paper, WP/09/116.

INTERNATIONAL MONETARY FUND. 2011. About the IMF: Governance Structure. <http://www.imf.org/ external/about/govstruct.htm>. Disponibilidade: 05 mar. 2013.

KIRTON, J. 2010. Assessing G8 and G20 Performance, 1975-2009. Paper presented at the international convention of the International Studies Association, New Orleans, p. 1-4.

2010. The G20 and Broader Multilateral Reform. Paper prepared for the preparatory meeting for the conference on 'What Role for the G20 in Post-Crisis World? FRIDE, Seoul, Korea, p. 1-12.

2001. The G20: Representativeness, Effectiveness and Leadership in Global Governance. In: KIRTON, J.; DANIELS, J.; FREYTAG, A. (Ed.) Guiding Global Order: G8 Governance in the Twenty-First Century, Aldershot: Ashgate.

KRIPPENDORF, K. 2004. Content Analysis: An Introduction to Its Methodology. 2nd ed., Thousand Oaks: Sage.

MIKHAYLOV, S.; LAVER, M.; BENOIT, K. 2008. Coder Reliability and Misclassification in Comparative Manifesto Project Codings. Paper presented at the 66th National Conference of the Midwest Political Science Association: Chicago.

VREELAND, J. 2010. Buying Bretton Woods. Georgetown University. Disponivel em: <http://www.econ. cam.ac.uk/silvaplana/papers/VreelandTubingen.pdf>. Acesso em: 05 mar. 2013.

2009. Governance at the International Monetary Fund. Georgetown University, p. 1-8. Disponivel em: <http://policydialogue.org/files/events/vree_transparency_conf.pdf>. Acesso em: 05 mar. 2013.

WOODS, N. 2010. Global Governance after the Financial Crisis: A New Multilateralism or the Last Gasp of the Great Powers? Global Policy, 1, p. 51-63. doi: 10.1111/j.1758-5899.2009.0013.x

2010. The G-20 Leaders and Global Governance. University College, Oxford, p. 3-15. 